\title{
EKSISTENSI WHATSAPP DALAM PEMBELAJARAN DI MASA PANDEMI: STUDI KASUS DI FAKULTAS SYARIAH IAIN METRO
}

\author{
Shely Nasya Putri \\ Fakultas Syariah, IAIN Metro Lampung \\ Pos-el: shelynasya@metrouniv.ac.id
}

\begin{abstract}
Abstrak
Penelitian ini bertujuan untuk mengkaji penggunaan Whatsapp dalam kegiatan pembelajaran di masa Pandemi Covid-19. Desain penelitian yang digunakan adalah penelitian studi lapangan. Jenis penelitian ini adalah deskriptif kualitatif. Subjek penelitian ini adalah mahasiswa Program Studi Hukum Ekonomi Syariah Fakultas Syariah IAIN Metro. Untuk mengetahui antusiasme siswa dalam menggunakan aplikasi Whatsapp dalam kegiatan pembelajaran, maka dibuatlah Grup Whatsapp. Berdasarkan penelitian, aplikasi Whatsapp dapat digunakan sebagai media pembelajaran online di masa pandemi. Meski tidak ada tatap muka, penggunaan Whatsapp mampu membuat pembelajaran terasa seperti tatap muka di kelas.

Kata kunci: WhatsApp, Pembelajaran, Pandemi, Studi Kasus
\end{abstract}

\begin{abstract}
This study aims to examine the use of WhatsApp in learning activities during the Covid-19 Pandemic. The research design used field study research. This type of research is descriptive qualitative. The research subjects were students of the Sharia Economics Law Study Program, Faculty of Sharia, IAIN Metro. In order to find out the enthusiasm of students in using the WhatsApp application in learning activities, a WhatsApp Group was created. Based on research, the Whatsapp application can be used as an online learning media during the pandemic. Even though there is no face to face, the use of WhatsApp is able to make learning feel like face to face in class.

Keywords: WhatsApp, Learning, Pandemic, Case Study
\end{abstract}




\section{PENDAHULUAN}

Covid-19 yang melanda dunia, khususnya Indonesia pada tahun 2020 resmi menjadi sebuah pandemi yang berdampak besar pada berbagai aspek kehidupan manusia, salah satunya pada bidang pendidikan. Guna mengutamakan pencegahan dan penularan Covid-19 ini, pemerintahpun mengambil sebuah kebijakan, yakni menunda kegiatan pembelajaran secara tatap muka.

Penyesuaian terhadap kebijakan pendidikan di masa pandemi tersebut mempengaruhi kebijakan pada berbagai tingkat pendidikan, termasuk perguruan tinggi keagamaan. Hal tersebut tercantum pada Surat Edaran Nomor: 657/03/2020 tentang Upaya Pencegahan Penyebaran Covid-19 di lingkungan Perguruan Tinggi Keagamaan Islam yang berbunyi, Pimpinan PTKI melakukan pengalihan, perkuliahan tatap muka menjadi pembelajaran jarak jauh mulai 16-29 Maret 2020 dan untuk selanjutnya akan dilakukan evaluasi.

Melihat kondisi pandemi Indonesia yang belum menunjukkan angka penurunan pada kasus pasien positif, selanjutnya dikeluarkan Surat Edaran Nomor 697/03/2020 tentang Perubahan atas Surat Edaran Direktur Jenderal Pendidikan Islam Nomor
657/03/2020 tentang Upaya Pencegahan Penyebaran Covid-19 di Lingkungan Perguruan Tinggi Keagamaan Islam yang berbunyi, Proses perkuliahan hingga akhir semester genap tahun akademik 20192020 pada setiap Perguruan Tinggi Keagamaan Islam baik negeri maupun swasta sepenuhnya dilakukan dalam jaringan (online) (Kemenag, 2020). Guna menindaklanjuti surat edaran tersebut, Rektor IAIN Metro pun turut mengeluarkan surat edaran terkait dengan proses perkuliahan di masa pandemi Covid-19, yang pada garis besarnya pembelajaran di IAIN Metro dilaksanakan secara online (daring).

Demi terwujudnya kegiatan pembelajaran yang lancar meski di situasi pandemi Covid-19 ini, maka kegiatan pembelajaran secara online harus didukung oleh keterampilan dosen dalam mengelola kegiatan pembelajaran. Hal tersebut mengingat bahwa mengajar merupakan suatu pekerjaan dengan tanggung jawab moral yang berat (Putri, 2018). Selain itu, kegiatan pembelajaran online dapat berjalan lancar dengan pengoptimtimalan dalam pemanfaatan berbagai perangkat serta platform berbasis teknologi. Salah satu perangkat teknologi yang saat ini paling popular dan dimiliki oleh hampir seluruh mahasiswa adalah 
gawai/handphone. Selain itu, kelebihan dari gawai dibandingkan dengan perangkat yang lain adalah, praktis dan mudah dibawa kemanapun.

Menurut Traxler (2009:1), “Mobile-learning' is certainly not merely the conjunction of 'mobile' and 'learning'; it has always implicitly meant 'mobile e-learning'...'. Menurutnya, mobile-learning bukanlah sebuah konjungsi (penggabungan dari dua buah kata yang memiliki arti baru), tetapi adalah singkatan dari mobile e-learning. Secara sederhana, mobile-learning dapat diartikan dengan electronic learning with mobile device atau menggunakan perangkat mobile seperti smartphone untuk mengakses pembelajaran secara elektronik (e-learning). M-Learning merupakan bagian dari electroniclearning (e-Learning) sehingga, dengan sendirinya, juga merupakan bagian dari distance-learning (d-Learning).

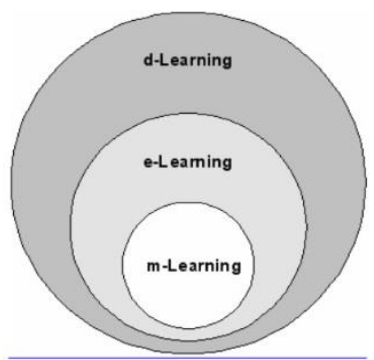

Gambar 2. Skema Bentuk mLearning

Mobile-learning dalam proses pembelajaran secara sederhana dapat diartikan sebagai sebuah proses penggunaan perangkat mobile dalam kegiatan pembelajaran. Perangkat ini seringkali dihubungkan dengan penggunaan smartphone yang menggunakan jaringan internet. Mobilelearning dapat didefinisikan sebuah tipe e-learning (electronic learning) yang menyampaikan konten pembelajaran dan material pendukung melalui perangkat komunikasi (Brown, 2005). Sejalan dengan pendapat tersebut, Traxler (dalam Hanafi dan Samsudin, 2012) menggambarkan bahwa mobile-learning sebagai pengaturan hubungan dan interaksi menggunakan perangkat komunikasi di kelas, baik pada saat pembelajaran kolaboratif maupun sebagai panduan pembelajaran. Menurut Sarrab (2012), terdapat tiga fungsi utama mobilelearning dalam proses pembelajaran, yaitu sebagai suplemen (tambahan), sebagai pelengkap (komplemen), dan sebagai substitusi (pengganti).

Berdasarkan beberapa pendapat tersebut maka dapat disimpulkan bahwa mobile-learning merupakan suatu jenis pembelajaran yang memanfaatkan perangkat komunikasi sebagai wahana pembelajaran. Perangkat tersebut dapat digunakan sebagai media ataupun sebagai alat untuk pemandu proses pembelajaran. 
Saat ini, Platform atau aplikasi yang popular di kalangan mahasiswa adalah Whatsapp. Selain mudah dan murah, fitur dalam Whatsapp juga cukup lengkap, mulai dari berkirim pesan, gambar, suara, dokumen, sampai dengan panggilan suara dan video call. Melalui aplikasi pesan lintas platform ini, mahasiswa dan dosen menjadi lebih mudah untuk berinteraksi melalui saling berkirim pesan, berdiskusi, dan membentuk grup (Whatsapp Group) untuk tujuan tertentu.

Penggunaan Whatsapp pada kegiatan pembelajaran memungkinkan terciptanya suasana pembelajaran yang lebih kondusif karena mahasiswa dapat mengakses kegiatan belajar dari mana pun dan kapan pun. Iklim pembelajaran menjadi lebih fleksibel dan santai. Kedekatan emosional yang baik juga akan terbentuk seiring meningkatnya intensitas komunikasi yang berdampak positif pada keaktifan mahasiswa dalam berkomunikasi melalui diskusi sehingga menjadikan banyaknya ide baru terkait materi pembelajaran. Berdasarkan kondisi yang diuraikan di atas, peneliti menerapkan pembelajaran secara online menggunakan Whatsapp.

Penelitian terdahulu telah membuktikan bahwa pemanfaatan Whatsapp dalam kegiatan pembelajaran memberikan pengaruh yang positif terhadap hasil belajar mahasiswa (Andika: 2016). Platform tersebut dapat menciptakan iklim belajar yang lebih efektif karena mampu memberikan kesempatan belajar yang lebih baik dan cepat bagi siswa. Selain itu, melalui materi yang telah diunggah, dapat memberikan peluang bagi siswa untuk dapat belajar di luar jam pengajaran formal.

Selanjutnya, Kartikawati (2017) juga mengungkapkan bahwa pemanfaatan Whatsapp dalam kegiatan pembelajaran memberikan pengaruh yang positif terhadap kemampuan berpikir kritis mahasiswa. Mahasiswa menjadi lebih termotivasi dalam kegiatan pembelajaran setelah menggunakan Whatsapp. Mahasiswa dapat belajar kapanpun dan dimanapun, serta merasakan suasana belajar yang tidak terlalu menegangkan seperti halnya saat belajar di kelas.

Berikutnya, Iskandar R (2020) dengan judul penelitian Penggunaan Grup Whatsapp sebagai Media Pembelajaran terhadap Peserta Didik DTA At-Tawakal Kota Bandung. Iskandar mengemukakan bahwa penggunaan Whatsapp Group mempermudah penyampaian materi pembelajaran. Siswa yang tidak hadir dan mengikuti pembelajaran tetap dapat memperoleh materi dengan cara 100 
mengunduh materi yang telah diunggah oleh guru.

Ketiga penelitian terdahulu belum menunjukan adanya aktivitas diskusi online menggunakan Whatsapp Group, sehingga pemanfaatan Whatsapp hanya berfungsi sebagai sumber belajar saja. Selain itu, pada ketiga penelitian tersebut belum sampai membahas tentang sikap mahasiswa terhadap penggunaan Whatsapp pada kegiatan pembelajaran.

\section{METODE PENELITIAN}

Metode penelitian yang digunakan olejh peneliti pada penelitian ini adalah studi lapangan. Penelitian ini merupakan sebuah penelitian deskriptif kualitatif. Data yang dikumpulkan berupa kata-kata, gambar, dan bukan angka-angka. Selain itu, data yang dikumpulkan kemungkinan menjadi kunci terhadap apa yang telah diteliti (Moleong, 2001: 6).

Subjek Penelitian ini adalah mahasiswa Program Studi Hukum Ekonomi Syariah Fakultas Syariah, IAIN Metro yang mengambil Mata Kuliah Bahasa Indonesia yang diampu oleh peneliti. Mahasiswa tersebut berjumlah 30 orang. Guna mencapai tujuan penelitian, peneliti membuat grup WhatsApp, dimana peneliti menjadi satusatunya admin dalam grup tersebut. Selanjutnya, 30 mahasiswa yang menjadi subjek penelitian dimasukkan dalam grup Whatsapp yang dibuat peneliti.

Data penelitian ini diambil melalui kuesioner, wawancara, dan observasi. Peneliti menggunakan media Whatsapp goup sebagai media pembelajaran secara daring, yaitu memberikan materi, diskusi, maupun tanya jawab dengan mahasiswa. Selanjutnya untuk mengetahui tingkat keberhasilan mahasiswa sekaligus membuktikan keefektifan Whatsapp Group dalam pembelajaran bahasa, maka dilakukan kegiatan wawancara akan dilakukan kepada 30 mahasiswa.

Responden dipilih berdasarkan pada pandangan awal mahasiswa terhadap pembelajaran online yang dilakukan sebelum kegiatan perkuliahan. Kegiatan wawancara ini bersifat Focus Group Discussion (FGD) dengan dipimpin langsung oleh peneliti dengan menggunakan Zoom Meeting. Responden memiliki kesempatan untuk berpendapat secara terbuka pada pertanyaan yang diberikan oleh peneliti. Responden diberi kesempatan untuk mengungkapkan pengalamannya selama mengikuti pembelajaran online menggunakan Whatsapp Group sebagai sarana komunikasi, diskusi, dan informasi dalam bertukar pikiran. 


\section{HASIL DAN PEMBAHASAN}

Berdasarkan hasil penelitian terhadap mahasiswa Program Studi Hukum Ekonomi Syariah Fakultas Syariah, IAIN Metro penggunaan Whatsapp dalam kegiatan pembelajaran menunjukkan bahwa mahasiswa tertarik dan lebih bersemangat mengikuti pembelajaran. Hal tersebut dilatarbelakangi oleh tampilan Whatsapp yang mudah serta praktis untuk digunakan.

Mahasiswa juga menyatakan bahwa Whatsapp merupakan aplikasi pesan lintas platform yang sangat cocok digunakan sebagai media dalam pembelajaran. Melalui Whatsapp, dosen dan mahasiswa dapat melakukan pembicaraan online baik melalui video call, chat dan berbagi materi pembelajaran dengan berbagai bentuk (foto, video, audio, maupun dokumen) secara gratis. Selain itu, komunikasi yang terjadi melalui Whatsapp Group layaknya belajar di kelas.

Penggunaan Whatsapp Group pada kegiatan pembelajaran mampu menciptakan suasana akademis yang kondusif karena mahasiswa bisa belajar dimana pun dan kapan pun. Implementasinya dalam pembelajaran mampu menghadirkan suasana belajar yang lebih fleksibel dan santai.
Kedekatan emosional antara dosen dan mahasiswa akan terbentuk seiring meningkatnya intensitas komunikasi melalui media tersebut. Selain itu, Whatsapp Group berdampak positif pada keaktifan mahasiswa dalam berdiskusi sehingga menjadikan banyaknya ide baru terkait pembelajaran sehingga semakin meningkatkan kemampuan berpikir kritis mahasiswa.

Berdasarkan penelitian ini maka dapat disimpulkan bahwa Whatsapp Group memiliki manfaat dalam pembelajaran, yaitu 1) memberikan fasilitas pembelajaran secara kolaboratif dan kolaboratif secara online antara guru dan siswa ataupun sesama siswa baik di rumah maupun di sekolah. 2) merupakan aplikasi gratis yang mudah digunakan. 3) dapat digunakan untuk berbagi komentar, tulisan, gambar, video, suara, dan dokumen. 4) memberikan kemudahan untuk menyebarluasakan pengumuman maupun mempublikasikan karya dalam grup. 5) Informasi dan pengetahuan dapat dengan mudah dibuat dan disebarluaskan melalui berbagai fitur yang ada di dalam Whatsapp.

\section{SIMPULAN}

Berdasarkan hasil penelitian, dapat ditarik kesimpulan bahwa Aplikasi Whatsapp dapat digunakan sebagai salah 
satu media pembelajaran daring di masa pandemi Covid-19. Meskipun tidak terjadi tatap muka, penggunaan Whatsapp mampu membuat pembelajaran terasa lebih hidup layaknya tatap muka di kelas. Kendala yang dihadapi saat memakai aplikasi Whatsapp adalah koneksi internet yang tidak stabil karena mahasiswa berada di berbagai daerah yang tidak semuanya memiliki akses internet yang stabil.

\section{DAFTAR PUSTAKA}

Anugrahana, A. (2018). Tinjauan Deskriptif Penerapan Higher Order Thinking dan ProblemBased Learning Pada Mata Kuliah Geometri Berdasarkan Kemampuan Matematika Mahasiswa. Scholaria: Jurnal Pendidikan Dan Kebudayaan, 8(2), 142-156.

Andika, Prajana. (2017). Pemanfaatan Aplikasi WhatsApp Dalam Media Pembelajaran di UIN Ar-Raniry Banda Aceh.Cyberspace: Jurnal Pendidikan Teknologi Informasi, 1 (2), 122-133.

Brown, T. (2005). M-Learning: Doing the unthinkable and reaching the unreachable! Diakses dari: http://learning.ericsson.net/mlearni ng2/the future_of mobile.shtml. pada 18 Mei 2021 pukul 15.00 WIB.

Cresswell, J.W. (2007). Educational Research: Planning, Conducting, and Evaluating Quantitative and Qualitative Research. (4th
Edition). New Jersey: Merill Prentice Hall.

Feldman, D. A. (2010). Berpikir Kritis, Strategi untuk Pengambilan Keputusan. Jakarta: PT Indeks.

Hanafi, Hafizul Fahri dan Khairulanuar Samsudin. (2012). Mobile Learning Environtment System (MLES): The Case of Androidbased Learning Application on Unidergraduates' Learning. International Journal of Advanced Computer Science and Application, 3 (3), 1-4.

Iskandar, R. (2020). Penggunaan Grup WhatsApp Sebagai Media Pembelajaran DTA At-Tawakal Kota Bandung. Comm-Edu (Community Education Journal) 3 (1), 97-101.

Jumiatmoko. (2016). WhatsApp Massenger dalam Tinjauan Manfaat dan Adab. Wahana Akademika, 3 (1), 51-66.

Kartikawati, Sulistyaning. Hendrik Pratama. (2017). Pengaruh Penggunaan WhatsApp Masenger sebagai Mobile Learning Terintegrasi Metode Group Investigation terhadap Kemampuan Berpikir Kritis. Jupiter (Jurnal Pendidikan Teknik Elektro), 2 (2), 33-38.

Low, P. \& Warawudhi, R. (2016). Undergraduates' Attitudes toward the Use of Facebook in Fundamental English Course. International Journal of Information and Education Technology, 6 (12), 934-938.

Putri, S.N. (2018). Analisis alih kode bahasa guru dalam pembelajaran 
Eksistensi Whatsapp dalam Pembelajaran...

di kelas bilingual. Kandai, 14 (1),

119-130.

Sarrab Mohamed, Laila Elgamel, dan Hamza Aldabbas. (2012). MobileLearning (M-Learning) and Educational Environments. International Journal of Distributed and Parallel Systems (IJDPS), 3 (4), 31-38.

Traxler, John. (2015). Learning in a Mobile Age. International Journal of Mobile and Blended Learning, 1 (1), 1-12.

Wayudi, Mauliana, Suwatno, Budi Santoso. (2020). Kajian Analisis Keterampilan Berpikir Kritis Siswa Sekolah Menengah Atas. Jurnal Pendidikan Manajemen Perkantoran, 5(1), 67-82.

Embodied Meaning, And Cognition. Cambridge: Cambridge University Press. 